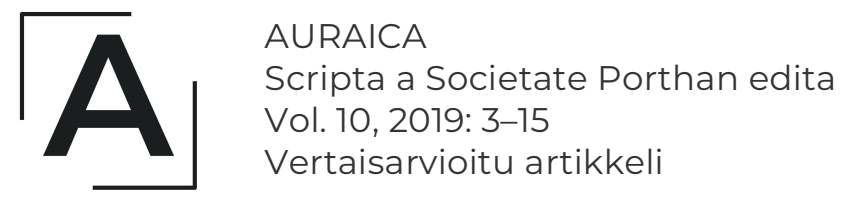

\title{
Karl Mestertonin väitöskirja rationalistisen filosofian ja eurooppalaisten vaikutteiden välittäjänä 1700-luvun puolivälin Turun akatemiassa
}

\author{
Visa Helenius
}

Turun akatemian teoreettisen filosofian professori ${ }^{1}$ Karl Mestertonin (1715-1773) väitöskirjan De principii rationis sufficientis adplicatione ad regnum materiale et immateriale - suomeksi Riittävän perusteen periaatteen soveltamisesta aineellisen ja aineettoman piirissä - tarkastustilaisuus oli 18. toukokuuta 1745. Mesterton käsittelee väitöskirjassaan riittävän perusteen periaatetta, joka on filosofinen periaate, jonka mukaan jokaisella olemassa olevalla asialla on jokin syy tai peruste. ${ }^{2}$ Tutkin artikkelissa tämän huonosti tunnetun väitöskirjan sisältöä ja kontekstia. Väitöskirjan suomennos ${ }^{3}$ julkaistaan artikkelin rinnalla.

\footnotetext{
${ }^{1}$ Kotivuori ja Oittinen käyttävät ko. virasta ilmausta "logiikan ja metafysiikan professuuri" (Yrjö Kotivuori, "Karl Mesterton", Ylioppilasmatrikkeli 1640-1852, Verkkojulkaisu, 2005; Vesa Oittinen, "Suomalainen filosofia 1200-1850", Ajatuksen kulku: suomalaiset filosofit maailmalla - maailman filosofit Suomessa, toim. Inkeri Pitkäranta, Helsingin yliopiston kirjasto - Suomen kansalliskirjasto, Helsinki, 2004, s. 30), Pietarinen taas käyttää ilmausta "teoreettisen filosofian professuuri" (Juhani Pietarinen, Suomalaisen filosofian vaiheita, Areopagus, Turku, 2015, s. 45). Käytän jälkimmäistä ilmausta artikkelissa.

${ }^{2}$ Riittävän perusteen periaate on nykytutkimuksen kohde. On tutkittu tai pohdittu muun muassa sitä, miten periaate on kehittynyt, mitä se tarkoittaa (ks. esim. Alexander Pruss, The Principle of Sufficient Reason - A Reassessment, Cambridge University Press, Cambridge, 2006, https://doi.org/10.1017/CBO9780511498992) ja onko maailmankaikkeudella riittävää perustetta tai syytä (ks. esim. Lawrence Krauss, A Universe from Nothing, Atria Paperback, New York, 2012).

${ }^{3}$ Karl Mesterton, "Riittävän perusteen periaatteen soveltamisesta aineellisen ja aineettoman piirissä", kääntänyt Visa Helenius, Auraica 10 (2019), s. 31-48.
} 


\section{Karl Mesterton ja Kuninkaallinen Turun akatemia}

Kuninkaallinen Turun akatemia, jota kutsutaan yleisesti Turun akatemiaksi, perustettiin vuonna 1640. Akatemian opetusta hallitsi lähes koko sen historian ajan teologinen tiedekunta. Erityisesti filosofiaa valvottiin, jotta vallitsevan teologian vastaisia oppeja ei pääsisi leviämään. Turun akatemiassa ei tuotettu kansainvälisesti merkittävää tutkimusta, koska akatemian päätehtävänä pidettiin virkamiesten kouluttamista. Toisaalta akatemian ansioista suomalainen tiede pysyi eurooppalaisen sivistyksen mukana. ${ }^{4}$ Akatemian toiminta siirrettiin Helsinkiin vuonna 1827 Turun palon jälkeen. ${ }^{5}$

Karl Mesterton syntyi Göteborgissa vuonna 1715 skottiperäiseen sukuun. Hänen isänsä oli Jakob Mesterton ja äitinsä Johanna Maria von Gerdes. Mesterton meni naimisiin Johanna Katarina Papken kanssa vuonna 1747. Pari sai kolme poikaa, Gustafin, Karl Jakobin ja Danielin. Mesterton kuoli Turussa 29. marraskuuta $1773 .{ }^{6}$ Hänen etunimensä esiintyy toisinaan muodossa Carl tai nimen latinalaistetussa muodossa Carolus.

Mesterton valmistui ylioppilaaksi Lundin yliopistossa 14. tammikuuta 1731 ja hänet vihittiin papiksi Lundin hiippakunnassa 24. maaliskuuta 1738. Tämän jälkeen Mesterton opiskeli lähes viisi vuotta Hollannissa ja Saksassa toimien muun muassa Helmstedtin yliopiston opettajana vuosina 1741 ja $1742 .{ }^{7}$ Mesterton väitteli tohtoriksi Turussa 1745 filosofian oppiaineessa. Seuraavana vuonna hän sai Turun akatemian teoreettisen filosofian professuurin, jossa hän toimi vuoteen 1767 asti. Mestertonin edeltäjä virassa oli Johan Welin ${ }^{8}$ (n. 1705-1744 ${ }^{9}$ ), ja hänen jälkeensä virkaan astui Jakob Haartman (1717-1788 $\left.{ }^{10}\right) .{ }^{11}$ Professuurin ohella Mesterton toimi Turun akatemian rehtorina vuosina 1754, 1755, 1764 ja 1765 sekä Piikkiön (1748) ja Paimion (1757) kirkkoherrana. Myöhemmin, vuonna 1767, hän sai teologian professuurin Turun akatemiassa. $^{12}$

Filosofiassaan Mesterton oli sitoutunut wolffilaisuuteen, joka perustuu saksalaisen Christian Wolffin (1679-1754) ajatteluun. Mesterton jatkoi Turun akatemian wolffilaista perinnettä, sillä myös hänen edeltäjänsä Welin, joka oli ollut jopa Wolffin oppilaana, oli wolffilainen. Mesterton oli professorina toimelias: hänen johdollaan

\footnotetext{
${ }^{4}$ Pietarinen, Suomalaisen filosofian vaiheita, s. 17-18.

5 (i) Turun akatemian historiasta ks. Matti Klinge et al., Helsingin yliopisto 1640-1990: 1. osa, Kuninkaallinen Turun akatemia 1640-1808, Otava, Helsinki, 1987; Oittinen, "Suomalainen filosofia"; Pietarinen, Suomalaisen filosofian vaiheita. (ii) Turun akatemian sähköinen väitöskirjakokoelma: https://www.doria.fi/handle/10024/50699. (iii) Lista Turun Akatemian latinankielisten väitöskirjojen suomennoksista: https://filosofia.fi/tallennearkisto/tekstit/5614.

${ }^{6}$ Kotivuori, "Karl Mesterton".

${ }^{7}$ Kotivuori, "Karl Mesterton".

${ }^{8}$ Welin oli ensimmäinen suomalainen Royal Societyn jäsen. Jäsenyyden saamisessa auttoi luultavasti hänen sosiaalinen lahjakkuutensa ja laajat yhteydet tiedemaailmassa. Welin kuoli nuorena tapaturmaisesti Pariisissa. (Pietarinen, Suomalaisen filosofian vaiheita, s. 44-45.)

${ }^{9}$ Yrjö Kotivuori, ”Johan Welin", Ylioppilasmatrikkeli 1640-1852, Verkkojulkaisu, 2005.

${ }^{10}$ Yrjö Kotivuori, "Jakob Haartman", Ylioppilasmatrikkeli 1640-1852, Verkkojulkaisu, 2005.

${ }^{11}$ Oittinen, "Suomalainen filosofia", s. 27, 30.

${ }^{12}$ Kotivuori, "Karl Mesterton".
} 
julkaistiin lähes sata väitöskirjaa ja wolffilaisuus jatkui menestyksekkäänä Turun akatemiassa Welinin ja matematiikan professori Nils Hasselbomin (1690-1764 ${ }^{13}$ ) viitoittamalla tiellä. Hasselbom, joka oli tullut Uppsalasta Turkuun vuonna 1724, oli wolffilaisuuden varsinainen vakiinnuttaja Turun akatemiassa. ${ }^{14}$

\section{Rationalismi, riittävän perusteen periaate ja wolffilaisuus}

Mestertonin Riittävän perusteen periaatteen soveltamisesta aineellisen ja aineettoman piirissä liittyy wolffilaiseen rationalismiin, jonka keskiössä on riittävän perusteen periaate. Selvennän seuraavaksi keskeisiä käsitteitä rationalismi, riittävän perusteen periaate ja wolffilaisuus. ${ }^{15}$

Rationalismi on filosofian suuntaus, jossa painotetaan inhimillistä järkeä ja sen ominaisuuksia. Rationalismin vastakohtana on usein pidetty empirismiä, jossa painotetaan aistien toimintaa ja kokemusta. Vastakkainasettelu on osoittautunut ongelmalliseksi, koska rationalistit ja empiristit jakavat samoja filosofisia oletuksia. ${ }^{16}$

Rationalismilla tarkoitetaan usein rationalistista epistemologiaa eli rationalistista tietoteoriaa. Sen mukaan tieto perustuu inhimilliseen järkeen. Toisin sanoen rationalistisen epistemologian mukaan ihmisen on mahdollista saavuttaa tietoa, koska ihmisellä on järki. Ihmisen tietokykyä rajoittaa kuitenkin seuraava: ihmiselle maailma on vain periaatteellisesti käsitettävissä, ei reaalisesti, koska ihminen on tieto- ja ymmärryskyvyltään rajallinen olento eikä ihminen voi ymmärtää täysin ääretöntä maailmankaikkeutta. Rationalistinen epistemologia voidaan jakaa vahvaan ja maltilliseen rationalistiseen epistemologiaan seuraavasti. Ensimmäisenä mainitun mukaan kaikki inhimillinen tieto on järjen ja vain järjen kautta saatu. Jälkimmäisenä mainitun mukaan myös kokemuksen kautta saadaan tietoa, vaikka järjellä on keskeisempi osuus tiedon saannissa. Näistä jälkimmäinen on ollut filosofian historiassa suositumpi, koska kokemustiedon olemassaolon kiistäminen on osoittautunut melko vakuuttamattomaksi.

Rationalistisen epistemologian lisäksi on olemassa rationalistista metafysiikkaa. Sen mukaan todellisuus on itsessään - tavalla tai toisella - rationaalinen. Rationalistisen metafysiikan väitteet eivät koske täten tietoa ja tiedonhankintaa vaan maailmaa kohteena. Rationalistisen metafysiikan kannattaja ajattelee siten, että se mikä on todellista, on myös rationaalista eli järjellistä ja järjellä käsitettävää. ${ }^{17}$

\footnotetext{
${ }^{13}$ Yrjö Kotivuori, "Nils Hasselbom", Ylioppilasmatrikkeli 1640-1852, Verkkojulkaisu, 2005.

${ }^{14}$ Oittinen, "Suomalainen filosofia", s. 27; Pietarinen, Suomalaisen filosofian vaiheita, s. 43, 45.

${ }^{15}$ Näistä käsitteistä laajemmin ks. esim. Visa Helenius, Riittävän perusteen periaate Leibnizilla, Wolffilla, Baumgartenilla ja esikriittisen kauden Kantilla olemassaoloa selitettäessä, lisensiaatintyö, Turun yliopisto, 2019, http://urn.fi/URN:NBN:fi-fe2019101833595.

${ }^{16}$ Ks. esim. Charlie Huenemann, Understanding Rationalism, Acumen, Slough, 2008, s. 1-2, https://doi.org/10.1017/UPO9781844654000.

17 Huenemann on tehnyt seuraavan jaottelun, joka selventää rationalistista epistemologiaa ja metafysiikkaa tarkemmin. Epistemologiaa koskien hyväksytään (i) a priori -totuudet eli totuudet, jotka eivät ole kokemuksesta riippuvia, (ii) ainakin joidenkin ideoiden synnynnäisyys ja (iii) ihmismielen kognitiivinen "koneisto" (engl. machinery), joka mahdollistaa järjen kohteiden ja kuvittelun kohteiden
} 
Riittävän perusteen periaate, johon viittaan tästä eteenpäin lyhenteellä $R P P$, on vahva mutta ongelmallinen filosofinen periaate. Sen mukaan yksikään eksistoiva eli olemassa oleva olio ei voi olla ilman jotakin syytä tai perustetta. Itsestään selvältä tuntuva RPP on osoittautunut ongelmalliseksi. Periaatteelle ei ole esimerkiksi kyetty esittämään uskottavaa todistusta. Ongelmien seurauksena on jouduttu taipumaan seuraavalle vaihtoehdolle: maailmassa saattaa olla sellaisia asioita, joilla ei ole perustetta tai syytä. Esimerkiksi maailmankaikkeus tai inhimillisen tahdon akti eli tahtomus saattavat olla olemassa ilman perustetta.

RPP:n juuret ulottuvat antiikin ajalle. Esimerkiksi Anaksimandroksen, jota pidetään Thaleen jälkeen seuraavana merkittävänä filosofina antiikin Kreikan esisokraattisessa filosofiassa, on esitetty ajatelleen siten, että Maan sijainti pysyy avaruudessa muuttumattomana, koska sen sijainnin muutokselle ei ole olemassa perustetta tai syytä. ${ }^{18}$ Kuitenkin vasta saksalainen Gottfried Wilhelm Leibniz (1646-1716) esitti uuden ajan alussa periaatetta koskevalle idealle nimen riittävän perusteen periaate ja muotoilun. ${ }^{19}$ RPP on ollut Leibnizia edeltävästi monessa filosofiassa piilevänä taustaoletuksena. ${ }^{20}$

Uuden ajan alussa tieteen löydöt ja kristinuskon opit ajautuivat keskinäisiin ongelmiin ja ristiriitoihin. Tuon ajan RPP:ta koskevissa keskusteluissa ilmenee kristinuskon oppien ja valistuksen sekä deismin välisiä jännitteitä. Uuden ajan alussa vaadittiin myös Jumalan olemassaolon aiempaa parempaa selittämistä ja perustelua. Rationalistit kokivat maailman olevan sellainen järjellinen kokonaisuus, missä jokaisella oliolla on riittävä peruste. Tämän puolestaan nähtiin tukevan oletusta Jumalan olemassaolosta tai jopa olevan sille todiste. ${ }^{21}$

Wolffilaisuus on eräs rationalismin keskeisistä suuntauksista. Sen perustaja, Christian Wolff, väitteli vuonna 1703 Leipzigin yliopistossa. Saatuaan naapurikaupungin eli Hallen yliopistosta matematiikan ja luonnonfilosofian professuurin vuonna 1707 Wolff alkoi kasvattaa mainettaan laadukkaan opetuksensa ja voimakkaiden filosofisten näkemystensä ansiosta. Epäonni näytti kuitenkin kohdanneen hänet vuonna 1723, kun Wolff karkotettiin Preussista: Hallen pietistit ja kuningas Fredrik Vilhelm I (1688-1740) olivat alkaneet paheksua hänen voimakkaita ja

erottamisen. Metafysiikkaa koskien hyväksytään (i) todellisuuden asteittaisuus (jolloin oliot ovat täydellisyyden asteen suhteen eriarvoisia), (ii) Jumalan ja (iii) sielun olemassaolo sekä (iv) oletus, että inhimillisellä järjellä on kyky paljastaa todellisuus. (Huenemann, Understanding Rationalism, s. 7, 12.)

${ }^{18}$ Aristoteles, "Taivaasta”, Teokset IV, kääntänyt Petri Pohjanlehto, Gaudeamus, Helsinki, 2003, s. 55.

${ }^{19}$ Ks. esim. Gottfried Wilhelm Leibniz, Filosofisia tutkielmia, kääntänyt Tuomo Aho et al., Gaudeamus, Helsinki, 2011, s. 328, 337.

${ }^{20}$ Vrt. esim. René Descartes, "Mietiskelyjä ensimmäisestä filosofiasta", Teokset II, kääntänyt Tuomo Aho \& Mikko Yrjönsuuri, Gaudeamus, Helsinki, 2002, s. 49-50; Baruch Spinoza, "The Principles of the Philosophy of René Descartes, Demonstrated in the Geometrical Manner", Earlier Philosophical Writings, transl. Frank A. Hayes, The Bobbs-Merrill Company, Indianapolis, 1963, s. 31; Baruch Spinoza, Etiikka, kääntänyt Vesa Oittinen, Gaudeamus, Helsinki, 1998, s. 51. Periaatteen historiasta ks. Helenius, Riittävän perusteen periaate, s. 14-18; Yitzhak Melamed \& Martin Lin, "Principle of Sufficient Reason", The Stanford Encyclopedia of Philosophy, ed. Edward N. Zalta (Spring 2018 Edition), 2016, luvut 1-4, https://plato.stanford.edu/archives/spr2018/entries/sufficient-reason/.

${ }^{21}$ Ks. esim. Leibniz, Filosofisia tutkielmia, s. 350. 
kiistanalaisia rationalistisia näkemyksiään. Karkotus ei yllättäen tuhonnut Wolffin uraa, vaan se jopa lisäsi hänen mainettaan Euroopassa. Karkotuksen aikana Wolff tuotti Marburgin yliopistossa keskeiset latinankieliset teoreettisen filosofian teoksensa. Vuonna 1740 Wolffin sallittiin palata Halleen, jossa hän laati käytännöllisen filosofian teossarjansa. Wolff kuoli vuonna 1754. Wolffin keskeinen panos eurooppalaiselle filosofialle on, että hän oli ensimmäinen, joka laati filosofisen systeeminsä ${ }^{2}$ latinan lisäksi myös saksaksi. ${ }^{23}$

Wolffin filosofia pohjautuu Leibnizin filosofiaan. Leibnizin idealistinen filosofia perustuu pluralistiselle ontologialle. Sen mukaan maailma koostuu useista substansseista eli todellisuuden perimmäisistä yksiköistä. Leibniz kutsuu näitä myöhäistuotannossaan monadeiksi. ${ }^{24}$ Monadien leimallisin piirre lienee se, että ne ovat henkisiä; monadit eivät siis ole aineellisia, materiaalisia atomeja, jollaisia ovat olettaneet filosofianhistoriassa muun muassa Demokritos, Epikuros ja Lucretius. Leibnizin ja Wolffin filosofiat on syytä erottaa toisistaan, koska niissä on niin sisällöllisiä kuin metodiikkaan liittyviä eroja. $^{25}$

Wolff uskoi, että järjen käyttö eli rationaalinen ja looginen ajattelu - johtaa onnelliseen elämään. Tämän seurauksena hän ajatteli, että valtion tulee ohjata kansalaisiaan järjen käyttöön ja tarpeen vaatiessa jopa pakottaa heidät siihen. ${ }^{26}$ Wolffilaisuus oli poikkeuksellisen suosittua osassa Keski-, Pohjois- ja Itä-Euroopan kaupungeista 1700 -luvun puolivälissä. ${ }^{27}$ Valistuksen kahdesta pääsuuntauksesta se kuului rationalismiin perustuvaan "järkivalistukseen" erotettuna empirismiin perustuvasta "hyötyvalistuksesta". Molemmat suuntaukset ulottuivat Turun akatemiaan..$^{28}$

Wolffilaisuus kukoisti Turun akatemiassa 1700-luvun puolivälin tienoilla nimenomaan Hasselbomin, Welinin ja Mestertonin johdolla. Mestertonin jälkeen wolffilaisuus alkoi kuitenkin näivettyä hedelmättömäksi ja akateemiseksi "kateederifilosofiaksi". Vaikka wolffilaisuuden vahva asema säilyi Turussa vielä senkin jälkeen, kun se oli jo muualla Euroopassa heikentynyt, lopulta Kantin kriittisen filosofian vaikutuksesta wolffilaisuus hävisi Turun akatemiasta. ${ }^{29}$ Wolffilaisuuden

\footnotetext{
${ }^{22}$ Wolffin filosofiasta ks. Matt Hettche, "Christian Wolff", The Stanford Encyclopedia of Philosophy, ed. Edward N. Zalta (Winter 2016 Edition), 2014, https://plato.stanford.edu/archives/win2016/entries/wolffchristian/.

23 Courtney Fugate \& John Hymers, "Introduction to the Translation", in Alexander Baumgarten, Metaphysics, Bloomsbury, London, 2014, s. 15-20; Hettche, "Christian Wolff", johdanto, 1. kappale; ibid., 1. luku; Christian Wolff, Philosophia prima sive ontologia method scientifica petractata qua omnis cognitionis humanae principia continentur, Georg Olms, Hildesheim, 2001.

${ }^{24}$ Ks. Leibniz, Filosofisia tutkielmia, s. 333-335.

${ }^{25}$ Fugate \& Hymers, "Introduction to the Translation", s. 15-17; Hettche, "Christian Wolff", 2. luku; Oittinen 2004, 26 ja 27.

${ }^{26}$ Pietarinen, Suomalaisen filosofian vaiheita, s. 42.

${ }^{27}$ Oittinen, "Suomalainen filosofia", s. 27. Esimerkiksi Pietari I (1672-1725) yritti houkutella Wolffia perustamansa tiedeakatemiansa esimieheksi Venäjälle. (Oittinen, "Suomalainen filosofia", s. 27.)

${ }_{28}$ Pietarinen, Suomalaisen filosofian vaiheita, s. 41 ja 42. Lainausmerkeillä rajatut ilmaukset ovat Pietarisen.

${ }^{29}$ Pietarinen, Suomalaisen filosofian vaiheita, s. 46, 53-57. Lainausmerkeillä rajattu ilmaus on Pietarisen.
} 
kovimpia vastustajia akatemiassa oli suomalaissyntyinen Peter Forsskål (1732-1763). Radikaaliempiristinä hän kyseenalaisti ristiriidan periaatteen ${ }^{30}$ ja RPP:n, jotka ovat Leibnizin ja Wolffin filosofioiden ehdottomia lähtökohtia. ${ }^{31}$

Niin sanotun kriittisen kauden Immanuel Kant (1724-1804) kritisoi voimakkaasti Wolffin rationalismia: hänen mukaansa Wolffin filosofia on dogmaattista rationalismia, koska Wolff ei ole asettanut järkeä ja sen toimintoja kriittisen tarkastelun alaiseksi. Wolffilaiset eivät kyenneet puolustautumaan Kantin kritiikkiä vastaan onnistuneesti. Viimein, 1700-luvun jälkipuolella, kantilaisuus ja Britanniasta Manner-Eurooppaan rantautunut empirismi syrjäyttivät wolffilaisuuden Euroopan yliopistoista. ${ }^{32}$

\section{Mestertonin väitöskirja Riittävän perusteen periaatteen soveltamisesta aineellisen ja aineettoman piirissä}

Riittävän perusteen periaatteen soveltamisesta aineellisen ja aineettoman piirissä on kirjoitettu Turun akatemiassa 1700-luvun keskivaiheilla vallinneen wolffilaisuuden vaiheessa. Mesterton on mahdollisesti hakenut teoreettisen filosofian professorin virkaa kyseessä olevalla väitöskirjalla, ${ }^{33}$ joka olisi tässä tapauksessa joko pro munere -väitöskirja eli virkaa varten tehty väitöskirja tai pro professoratu -väitöskirja eli professuuria varten tehty väitöskirja. ${ }^{34}$ Toisaalta kyseinen väitöskirja saattaa olla Mestertonin pro doctoratu -väitöskirja eli tohtorinväitöskirja, jolloin respondentin rooli väitöksen teossa saattaa olla huomattava. Väitöksen respondentti ${ }^{35}$, Niklas Agander (1722-1803), tuli Wiipurilaisesta osakunnasta. ${ }^{36}$ Vaikka Aganderia koskevassa Ylioppilasmatrikkelitietokannassa Mestertonin väitös esitetään Aganderin pro exercitio -väitöskirjaksii ${ }^{37}$, niin seuraavat seikat ovat tätä vastaan: (i) kannen ilmaus "Suurimman akatemian hallinnon toimeksiannosta" 38 viittaa pro munere, pro professoratu tai pro doctoratu -väitökseen; (ii) Mestertonia ei mainita kannessa preeseksenä ${ }^{39}$ (lat. praeses) vaan auktorina (lat. auctor) eli tekijänä; (iii) respondentti esitellään ablatiivimuodolla (lat. respondente,

\footnotetext{
${ }^{30}$ Ristiriidan periaatteen mukaan yksikään asia ei voi olla samanaikaisesti tosi ja epätosi.

${ }^{31}$ Oittinen, "Suomalainen filosofia", s. 30-31.

${ }^{32}$ Pietarinen, Suomalaisen filosofian vaiheita, s. 43, 47-48.

${ }^{33}$ Oittinen, "Suomalainen filosofia", s. 27.

${ }^{34}$ Kauko Kouvalainen, ”Turun akatemian väitöskirjat”, Lääketieteellinen Aikakauskirja Duodecim, 124 (18), 2008, s. 2109. Turun akatemian väitöskirjatyypeistä ja tekijän suhteen ongelmallisesta menettelytavasta ks. myös Inkeri Kinnari, "Antiikkia Turun akatemiassa", Philologia classica, toim. Tiina Hiekkalinna \& Minna Seppänen, Klassilliset kielet ja antiikin kulttuuri, Turun yliopisto, 2010, s. 171-181.

${ }^{35}$ Respondentti puolusti preeseksen eli ohjaajan nimiin laitettua väitöskirjaa väitöstilaisuudessa omaa oppiarvoaan tavoitellen.

${ }^{36}$ Yrjö Kotivuori, "Niklas Agander", Ylioppilasmatrikkeli 1640-1852, Verkkojulkaisu, 2005.

${ }^{37}$ Pro exercitio -väitöskirja: harjoitusväitöskirja kandidaatin- tai maisterintutkinnon osana.

${ }^{38}$ Ks. Karl Mesterton, "Riittävän perusteen periaatteen soveltamisesta aineellisen ja aineettoman piirissä", kääntänyt Visa Helenius, Auraica 10 (2019), s. 34. Lat. "Ex mandato Ampliss. Senatus Academici". Carolus Mesterton, De principii rationis sufficientis adplicatione, 1745, URL: http://www.doria.fi/handle/10024/109336, s. i.

${ }^{39}$ Preeses ohjasi usein väitöskirjan ja toimi väitöstilaisuudessa esimiehenä ja tiedekunnan edustajana sekä esitteli väitöskirjan ja osallistui siitä käytävään keskusteluun respondentin ollessa usein työn todellinen tekijä. Toisaalta esimerkiksi Henrik Gabriel Porthan kirjoitti itse oletettavasti valtaosan hänen nimiinsä laitetuista filosofisista töistä. (Pietarinen, Suomalaisen filosofian vaiheita, s. 72, n. 37.)
} 
respondentin avulla), joka saattaa kertoa siitä, että respondentti ei ole kirjoittanut väitöskirjaa; (iv) työn lopussa ei ole pro exercitio -väitöskirjan tavanomaisia preeseksen kirjoittamia teesejä, joilla on testattu respondentin oppineisuutta; (v) gratulaatiot on osoitettu Mestertonille eikä Aganderille; (vi) Mesterton sai seuraavana vuonna filosofian professuurin. Näin ollen väitöskirja lienee todennäköisesti pro munere, pro professoratu tai pro doctoratu -väitöskirja, jota Agander on puolustanut kandidaatin oppiarvon ${ }^{40}$ saamiseksi. Erityisesti auctor-sanan takia oletan artikkelissa, että Mesterton on väitöskirjan pääasiallinen tekijä.

Väitöskirja koostuu otsikkosivusta tekijä- ja kirjanpainajatietoineen ${ }^{41}$, alun kahdesta gratulaatiosta $^{42}$, joista ensimmäinen on 2 sivun mittainen ja jälkimmäinen yhden, ja itse dissertaatiosta, joka on 18 sivun mittainen. Väitöskirja koostuu kahdesta osasta, joista ensimmäinen sisältää seitsemän osiota ja jälkimmäinen neljä. Väitöskirja on kirjoitettu pääasiallisesti latinaksi. Poikkeuksen muodostavat jälkimmäinen gratulaatio, joka on ranskankielinen, ja kolme saksankielisestä lainausta, joiden yhteenlaskettu pituus on noin 3 sivua. Mesterton viittaa väitöskirjassaan useisiin henkilöihin ja teoksiin. Käsittelen väitöskirjaan sisältyviä lainauksia ja siinä mainittuja henkilöitä ja teoksia suomennoksen alaviitteissä.

Mesterton käsittelee väitöskirjassaan RPP:ta sekä esittää huomioita periaatteen soveltamisesta wolffilaisessa viitekehyksessä. Väitöskirjan ensimmäisen osan ensimmäisessä osiossa Mesterton johdattelee tutkielmansa aiheeseen eli RPP:ta koskevan tematiikan pariin. Johdatus on tosin suppea. Aluksi Mesterton viittaa eräisiin yleisiin käsityksiin periaatteesta. Hän viittaa myös Arkhimedeen tasapaino-oppiin sekä Kungfutsen etiikan teoriaan, kuten Wolff ja Leibniz ovat tehneet tuotannoissaan, ${ }^{43}$ joissa RPP:n on esitetty ilmenevän. Osion lopussa Mesterton suo Leibnizille erityistä kunniaa periaatteen keksimisestä, mutta toteaa kuitenkin, että Wolff on periaatteen kannalta merkittävämpi henkilö, koska hän systematisoi periaatetta ja esittää sille tehokkaan ja luotettavan todistusargumentin. ${ }^{44}$

Väitöksen ensimmäisen osan toisessa osiossa Mesterton tarkastelee RPP:n sisältöä ja merkitystä tarkemmin. Ensin hän esittää periaatteen erään yleisen muotoilun, joka on seuraavanlainen: "mikään ei ole olemassa ilman riittävää perustetta" ja "se, mikä on olemassa, sisältää riittävän perusteen". ${ }^{45}$ Tämän jälkeen Mesterton esittää käsitteet tyhjä asia, tyhjä käsite ja ei mikään sekä selittää Wolffin mukaisesti, että oletus tyhästä syntyneestä asiasta on absurdi, koska järki osoittaa selvästi, että yksikään olio ei ole

\footnotetext{
${ }^{40}$ Mesterton, "Riittävän perusteen periaatteen soveltamisesta", s. 48.

${ }^{41}$ Mesterton, "Riittävän perusteen periaatteen soveltamisesta", s. 35.

${ }^{42}$ Gratulaatio tarkoittaa muodollista onnittelua. Kyseiset onnittelijat ovat Georg Ehrenmalm (1723-1807)

ja ilmeisesti joko Henrik Pipping (1718-1767) tai hänen veljensä Jost Joakim Pipping (1720-1793).

${ }^{43}$ Leibniz, Filosofisia tutkielmia, s. 350; Wolff, Philosophia prima, s. 52.

44 Ks. Wolff, Philosophia prima, s. 47, 51-52. Kohdissa Wolff esittää RPP:lle kokemuksesta riippumattoman eli a priori -todistuksen sekä selventää, miten RPP voidaan johtaa kokemuksesta eli a posteriori.

${ }^{45}$ Mesterton, "Riittävän perusteen periaatteen soveltamisesta", s. 39. Lat. "Nihil est sine ratione suffciente: vel quicquid est, rationem habet sufficientem." (Mesterton, De principii rationis sufficientis, s. 2, 3.)
} 
voinut syntyä tyhjästä. Mestertonin esittämä edellinen väite on siinä mielessä ongelmallinen, että ajatus tyhjästä syntyneestä oliosta ei vaikuta loogisesti ja käsitteellisesti ristiriitaiselta. Toisin sanoen tällainen olio vaikuttaa loogisesti ja käsitteellisesti mahdolliselta. Osion lopuksi Mesterton selventää, että vaikka inhimillinen järki ei voi ymmärtää kaikkia asioita, se ymmärtää kuitenkin helposti, mitä riittävä peruste tarkoittaa.

Ensimmäisen osan kolmannessa osiossa Mesterton selventää RPP:n ideaa lisää. Hän viittaa sekä Wolffiin että saksalaiseen filosofiin Georg Bernhard Bilfingeriin (16931750), joka oli Leibnizin ja Wolffin oppien kannattaja. Mesterton valaisee periaatetta Bilfingerin käsityksen kautta: riittävä peruste saa aikaan seurauksen eli peruste on ikään kuin tietyn liikkeen aikaan saanut liikuttaja. Osion lopuksi Mesterton esittää, että inhimilliselle teolle on peruste eli ajattelu ja harkinta toimivat perusteena seuraukselle eli teolle. Näin ollen ihminen ei toimi ilman perusteita eli sattumanvaraisesti tai yhdentekevästi. Perusteiden pohjalta toimiminen taas mahdollistaa moraalin syntymisen ja moraalisen toiminnan.

Ensimmäisen osan neljännessä osiossa Mesterton siirtyy tarkastelemaan RPP:n yhteyttä aineellisen piiriin eli luontoon liittyen. Hän esittää, että Jumalan luoma maailma, aineellinen maailma ${ }^{46}$, heijastaa riittävän perusteen periaatteen toimintaa monilla tavoilla. Maailman kaikki asiat ovat nimittäin juuri niin kuin ne ovat, koska Jumala on näin halunnut. Esimerkiksi auringon toiminta on täysin välttämätöntä maapallon kaikelle elämälle. Mesterton pyrkii tehostamaan väitettään esittämällä lainauksen Plinius vanhemman (23-79) Luonnonhistoriasta ${ }^{47}$, jossa Plinius esittää auringon olevan jumalallinen voima ja maapallolle "henki ja mieli"48.

Ensimmäisen osan viidennen osion alussa Mesterton esittää, viitaten kirkkoisä Augustinuksen (354-430) huomautukseen Jumalan valtio -teoksessa, että emme voi hyväksyä Anaksimeneen, erään esisokraatikon, ajatusta, että kaikki perustuu äärettömään ilmaan. Tekstissä mainitsematon syy tälle on se, että Mestertonin kannattamassa wolffilaisuudessa oletetaan henkiset substanssit kaiken perustaksi, jotka eroavat Anaksimeneen äärettömästä ilmasta. Mesterton esittää seuraavaksi, että ilma on itsessään todiste Jumalan ja RPP:n toiminnasta. Hän perustaa väitettään esittämällä englantilaisen luonnontieteilijä John Rayn (1627-1705) erään runollisen ajatuksen: ilma on "elämänliekki"49, joka on kaikille elollisille välttämätön. Tämän jälkeen Mesterton esittää saksalaisen teologi Caspar Calvörin (1650-1725) edellisen ajatuksen kanssa yhtäläisen mutta pidemmän ajatuksen sitaatissa. Calvörin mukaan ilma on "luonnon ihmetyö"50, joka ravitsee kaikkia elollisia. Kohdassa Calvör selittää niin ikään runolliseen sävyyn, miten ilma mahdollistaa maapallon elollisten elämän ja miten maapallo ilmakehineen heijastaa Jumalan viisautta, hyvyyttä ja kaikkivaltiutta. Tämän osion

\footnotetext{
${ }^{46}$ Lat. "regnum naturae vel materiale". Mesterton, De principii rationis sufficientis, s. 5.

${ }^{47}$ Lat. Naturalis historia.

${ }^{48}$ Lat. "animum ac [-] mentem". Mesterton, De principii rationis sufficientis, s. 6.

${ }^{49}$ Saks. "die lebens flamme". Mesterton, De principii rationis sufficientis, s. 7.

${ }^{50}$ Saks. "wunderwerck der natur". Mesterton, De principii rationis sufficientis, s. 7.
} 
tarkoituksena on vakuuttaa ilman olemassaolon kautta se, että kaikki luonnossa on harkittua ja perusteltua.

Ensimmäisen osan kuudennessa ja lyhyessä osiossa Mesterton toteaa, että esimerkiksi Raamatun vedenpaisumuksessa kuvatulle vuorten kohoamiselle on riittävät perusteet. Hän vetoaa asiassa opettajaansa ja suojelijaansa, ${ }^{51}$ Turun piispa ja Turun akatemian teologian professori Johan Browalliukseen (1707-1755), joka on mitä ilmeisimmin sitoutunut edelliseen näkemykseen. Tämä taas antaa viitettä kristinuskon oppien ja auktoriteetin läsnäolosta Mestertonin ajattelussa. Osion lopuksi Mesterton esittää, että korkealle kohonneet vuoristot hajottavat tuuli- eli säärintamat, jotka puolestaan siirtävät auringosta itseensä imemäänsä lämpöä paikasta toiseen.

Seitsemännessä osiossa, joka on väitöskirjan ensimmäisen osan viimeinen, Mesterton perustelee RPP:ta luonnon teleologisuudella eli tarkoituksenmukaisuudella: luonnon tapahtumille on niiden päämääriä koskevat perusteensa, kuten esimerkiksi sateella, joka on seuraus veden haihtumisesta ja yhdistymisestä sekä tuulen toiminnasta, sillä tuulten suunnan seurauksena sateet ilmenevät epätasaisesti eri alueilla. Samassa yhteydessä Mesterton viittaa Wolffin kahteen teleologisuutta koskevaan ajatukseen. Ensimmäiseksi tuuli mahdollistaa kosteuden siirtymisen paikasta toiseen. Toiseksi tuuli tuo eniten hyötyä kaikista sääolosuhteista ihmiselle. Osion lopuksi Mesterton esittää viittaukset Wolffin, Rayn ja hollantilaisen filosofin ja luonnontieteilijän Bernard Nieuwentijtin (1654-1718) teoksiin, joissa käsitellään luonnon teleologisuuteen liittyviä asioita.

Väitöksen jälkimmäinen osa käsittelee todellisuuden aineetonta puolta eli ihmismieltä. Tämän osan ensimmäisen osion alussa Mesterton esittää, että RPP:ta voidaan soveltaa ihmisen henkiseen toimintaan. Hän myös selittää käsitteitä moraalisen hyvän mielikuva, halu ja vastenmielisyys. Mestertonin mukaan ihmisen tahto on aidosti vapaa, vaikka sen toiminta perustuu perusteisiin..$^{52}$ Hän vetoaa asiassa Bilfingeriin, joka ajattelee Leibnizin ja Wolffin näkemysten mukaisesti: vastuullisuus vaatii vapaan tahdon, mistä seuraa hyvää ja pahaa koskevat rationaaliset valinnat. Toisin sanoen ihminen määrää itse omasta toiminnastaan, jolloin hyvä teko valitaan hyvän itsensä takia ja paha tietämättömyydestä. Mesterton myös kertoo lyhyesti Lundin akatemiassa syntyneestä ongelmallisesta näkemyksestä, joka päätyy lopputulokseen, että ihminen kykenee valitsemaan ja valitseekin tietoisesti pahan. Mesterton kumoaa tämän voimakkaasti vetoamalla kokemukseen ja muihin filosofeihin. Osion lopuksi Mesterton esittää, että Turun akatemian opettaja Gabriel Heinricius (n. 1710-1785) ja

\footnotetext{
${ }^{51}$ Lat. "Fautoris mei et Patroni". Mesterton, De principii rationis sufficientis, s. 9, 10.

${ }^{52}$ Leibnizin ja Wolffin tahdonvapauskäsitykset voidaan tulkita kompatibilismiksi, jonka mukaan vapaa tahto ja determinismi ovat yhteensopivat niiden näennäisestä yhteensopimattomuudesta huolimatta. Leibnizin ja Wolffin kohdalla keskeinen ajatus on se, että Jumala tietää jo maailmanluontia edeltävästi kaikkien mahdollisten vapaiden olentojen vapaasti valitut halut. Nämä halut syntyvät täten näissä olioissa mutta ne liittyvät olennaisesti myös muihin olioihin. Näin aktuaalisen maailman kaikilla vapailla olioilla on perusteisiin perustuva vapaa tahto. Tällaista näkemystä on pidetty kuitenkin ongelmallisena.
} 
kaunopuheisuuden professori Henrik Hassel (1700-1776) ovat ajatelleet Mestertonin kannattaman näkemyksen lailla.

Jälkimmäisen osan toisessa osiossa Mesterton käsittelee niin sanottua ekvivalenttien eli samanarvoisten vaihtoehtojen ongelmaa: mikäli valintatilanteessa on täysin samanarvoiset vaihtoehdot, niin on ajateltu, että valitsija ei kykene tekemään lainkaan valintaa, koska perusteet molemmille vaihtoehdoille ovat ekvivalentit eli samanarvoiset. Kohdassa Mesterton käsittelee Bilfingerin, sveitsiläiseen teologin ja filosofin Jean-Pierre de Crousazin (1663-1750) ja saksalaiseen filosofin ja teologin Israel Gottlieb Canzin (1690-1753) ajatuksia. Viimeisenä mainittuun vedoten Mesterton esittää ekvivalenttien vaihtoehtojen ongelmalle ratkaisun: valintatilanne ei voi päättyä koskaan valitsijan kykenemättömyyteen valita tai täysin satunnaiseen valintaan, koska valitsija tekee tosiasiassa samanarvoisten vaihtoehtojen kohdalla erilaisia tarkasteluja ja pohdintoja, joiden perusteella hän tekee lopulta valintansa.

Jälkimmäisen osan kolmannessa osiossa Mesterton käsittelee RPP:n suhdetta moraaliseen toimintaan ja vastuullisuuteen. Hän viittaa asiassa Canzin yhdeksänkohtaiseen revisioivaan jaotteluun. Näkemyksessä ihmisen henkiseen toimintaan liittyen objektiivisia eli ulkoisia perusteita pidetään epähyväksyttävinä, koska ihminen toimii sisäisten perusteidensa pohjalta Nämä perusteet mahdollistavat moraalisen vastuullisuuden. Canzin jaottelussa käydään läpi toiminnan eri motiiveja. Esimerkiksi harkitussa murhassa ${ }^{53}$ motiivina on pahuus ja kuoleman tietoinen ja aktiivinen tuottaminen, kun taas moraalisesti parhaimmassa teossa teon motiivina on muille tuotettu hyöty ja apu ilman tekijän omaa etua. Canzin jaottelu on mielenkiintoinen, ja se kertoo tuon ajan oikeuslaitoksen ja filosofian yhteisistä pohdinnoista.

Jälkimäisen osan neljännessä ja koko väitöskirjan viimeisessä osiossa Mesterton osoittaa loppusanat kandidaatin oppiarvoa tavoittelevalle Aganderille.

Väitöskirjan viittaukset ovat tarkastukseni perusteella mainituista lähteistä. Aivan sanatarkkoja kaikki lainaukset eivät tosin ole. Esimerkiksi Calvörin saksankielisestä sitaatista puuttuu useita kohtia ilman mainintaa. Lisäksi samaan kohtaan liittyy eräitä muuttuneita muotoja ja kirjoitusvirheitä.

Mestertonin väitöskirjan filosofinen arvo on siitä syystä pienehkö, että hän ei osoita juuri lainkaan itsenäistä ajattelua eikä kriittisyyttä RPP:ta ja käyttämiään lähteitään kohtaan. Väitöskirjan keskeisenä ideana on se, että Mesterton esittää jonkin RPP:ta koskevan väitteen, jota hän puolustaa lähes poikkeuksetta jonkun muun esittämällä ajatuksella. Työ on kuitenkin historiallisesti ja filosofianhistoriallisesti merkityksellinen. Ensinnäkin se sisältää lukuisia viittauksia eri henkilöihin ja teoksiin, joita ei tavanomaisesti mainita tai käsitellä RPP:ta koskevassa keskustelussa. Toiseksi se selventää sisältönsä ja lähteidensä puolesta Turun akatemiassa 1700-luvun puolivälissä vallinneen wolffilaisuuden vaihetta huomionarvoisesti.

\footnotetext{
${ }^{53}$ Lat. homicidium dolosum. Mesterton, De principii rationis sufficientis, s. 15.
} 


\section{Yhteenveto}

Vuonna 1745 julkaistussa väitöskirjassaan Riittävän perusteen periaatteen soveltamisesta aineellisen ja aineettoman piirissä Karl Mesterton käsittelee riittävän perusteen periaatteen sisältöä ja soveltamista. Työn tausta liittyy 1700-luvun rationalistiseen filosofiaan ja erityisesti wolffilaiseen rationalismiin. Työn ensimmäisen osan kolmessa ensimmäisessä osiossa Mesterton valottaa kyseisen periaatteen merkitystä ja siihen liittyviä keskeisiä käsitteitä. Ensimmäisen osan neljässä jälkimmäisessä osiossa Mesterton selventää riittävän perusteen periaatteen suhdetta aineellisen piiriin eli luontoon. Periaatteen olemassaoloa ja toimintaa perustellaan tällöin luonnon toiminnan kautta. Työn jälkimmäisen osan kolmessa ensimmäisessä osiossa Mesterton selventää periaatteen ja aineettoman piirin eli ihmismielen suhdetta. Mesterton pyrkii kytkemään tässä osassa riittävän perusteen periaatteen, ihmisen vapaan tahdon ja moraalisuuden toisiinsa eri ajattelijoihin viittaamalla ja erilaisia esimerkkejä käyttäen. Mestertonin väitöskirja osoittautuu historiallisesti ja erityisesti filosofianhistoriallisesti huomionarvoiseksi, koska siinä viitataan eri henkilöihin ja teoksiin ja se havainnollistaa osaltaan sitä, miten Turun akatemia oli kytkeytynyt eurooppalaiseen oppineeseen keskusteluun. Filosofisesti väitöskirja ei kuitenkaan ole kovin merkittävä, koska Mesterton ei osoita itsenäisyyttä eikä kriittisyyttä riittävän perusteen periaatetta tai käyttämiään lähteitä kohtaan. Toisaalta uuden luominen ei ole ollut Turun akatemiassa koskaan velvollisuus, sillä akatemian päätehtävänä pidettiin virkamiesten kouluttamista. ${ }^{54}$

Visa Helenius

VTL, tohtorikoulutettava

Filosofia

HuK, perustutkinto-opiskelija

Klassilliset kielet ja antiikin kulttuuri

Turun yliopisto

vjhele (apud) utu.fi

\section{Kirjallisuus}

Aristoteles, "Taivaasta", Teokset IV, kääntänyt Petri Pohjanlehto, Gaudeamus, 2003, Helsinki, s. 7-86.

Descartes, René, "Mietiskelyjä ensimmäisestä filosofiasta”, Teokset II, kääntänyt Tuomo Aho \& Mikko Yrjönsuuri, Gaudeamus, Helsinki, 2002, s. 19-316.

Fugate, Courtney \& John Hymers, "Introduction to the Translation", Alexander Baumgarten, Metaphysics, Bloomsbury, London, 2014, s. 1-65.

Helenius, Visa, Riittävän perusteen periaate Leibnizilla, Wolffilla, Baumgartenilla ja esikriittisen kauden Kantilla olemassaoloa selitettäessä, lisensiaatintyö, Turun yliopisto, 2019, URN: http://urn.fi/URN:NBN:fi-fe2019101833595.

\footnotetext{
${ }^{54}$ Kiitän kahta vertaisarvioijaa sekä Charlotta Wolffia ja Maria Lehtosta hyödyllisestä palautteesta.
} 
Hettche, Matt, "Christian Wolff", The Stanford Encyclopedia of Philosophy, ed. Edward N. Zalta (Winter 2016 Edition), 2014, URL: https://plato.stanford.edu/archives/win2016/entries/wolff-christian/. Noudettu 4.5.2019.

Huenemann, Charlie, Understanding Rationalism, Acumen, Slough, 2008, DOI: https://doi.org/10.1017/UPO9781844654000.

Kinnari, Inkeri, "Antiikkia Turun akatemiassa", Philologia classica, toim. Tiina Hiekkalinna \& Minna Seppänen, Klassilliset kielet ja antiikin kulttuuri, Turun yliopisto, 2010, s. 171-181.

Matti Klinge et al., Helsingin yliopisto 1640-1990: 1. osa, Kuninkaallinen Turun akatemia 1640-1808, Otava, Helsinki, 1987.

Kouvalainen, Kauko, "Turun akatemian väitöskirjat”, Lääketieteellinen Aikakauskirja Duodecim, 124 (18), 2008, s. 2108-2117.

Kotivuori, Yrjö, "Jakob Haartman", Ylioppilasmatrikkeli 1640-1852, Verkkojulkaisu, 2005, URL: https://ylioppilasmatrikkeli.helsinki.fi/henkilo.php?id=5647. Noudettu 27.5.2019.

Kotivuori, Yrjö, "Johan Welin", Ylioppilasmatrikkeli 1640-1852, Verkkojulkaisu, 2005, URL: https://ylioppilasmatrikkeli.helsinki.fi/henkilo.php?id=5434. Noudettu 27.5.2019.

Kotivuori, Yrjö, "Karl Mesterton”, Ylioppilasmatrikkeli 1640-1852, Verkkojulkaisu, 2005, URL: https://ylioppilasmatrikkeli.helsinki.fi/henkilo.php?id=U700. Noudettu 27.5.2019.

Kotivuori, Yrjö, "Niklas Agander", Ylioppilasmatrikkeli 1640-1852, Verkkojulkaisu, 2005, URL: https://ylioppilasmatrikkeli.helsinki.fi/henkilo.php?id=6663. Noudettu 30.5.2019.

Kotivuori, Yrjö, "Nils Hasselbom", Ylioppilasmatrikkeli 1640-1852, Verkkojulkaisu, 2005, URL: https://ylioppilasmatrikkeli.helsinki.fi/henkilo.php?id=U627. Noudettu 28.5.2019.

Krauss, Lawrence, A Universe from Nothing, Atria Paperback, New York, 2012.

Leibniz, Gottfried Wilhelm, Filosofisia tutkielmia, kääntänyt Tuomo Aho et al., Gaudeamus, Helsinki, 2011.

Melamed, Yitzhak \& Martin Lin, "Principle of Sufficient Reason", The Stanford Encyclopedia of Philosophy, ed. Edward N. Zalta (Spring 2018 Edition), 2016, URL: https://plato.stanford.edu/archives/spr2018/entries/sufficient-reason/. Noudettu 24. 11. 2019.

Mesterton, Carolus, De principii rationis sufficientis adplicatione. Aboae: excud. Joh. Kiaempe, Reg. Ac. typ., 1745, URL: http://www.doria.fi/handle/10024/109336.

Mesterton, Karl, "Riittävän perusteen periaatteen soveltamisesta aineellisen ja aineettoman piirissä”, kääntänyt Visa Helenius, Auraica 10 (2019), s. 31-48.

Oittinen, Vesa, "Suomalainen filosofia 1200-1850", Ajatuksen kulku: suomalaiset filosofit maailmalla - maailman filosofit Suomessa, toim. Inkeri Pitkäranta, Helsingin yliopiston kirjasto - Suomen kansalliskirjasto, Helsinki, 2004, s. 24-38.

Pietarinen, Juhani, Suomalaisen filosofian vaiheita, Areopagus, Turku, 2015.

Pruss, Alexander, The Principle of Sufficient Reason - A Reassessment, Cambridge University Press, Cambridge, 2006, DOI: https://doi.org/10.1017/CBO9780511498992.

Spinoza, Baruch, Etiikka, kääntänyt Vesa Oittinen, Gaudeamus, Helsinki, 1998. 
Spinoza, Baruch, "The Principles of the Philosophy of René Descartes, Demonstrated in the Geometrical Manner", Earlier Philosophical Writings, transl. Frank A. Hayes, The Bobbs-Merrill Company, Indianapolis, 1963, s. 11-103.

Wolff, Christian, Philosophia prima sive ontologia methodo scientifica pertractata qua omnis cognitionis humanae principia continentur, Georg Olms, Hildesheim, 2001. 